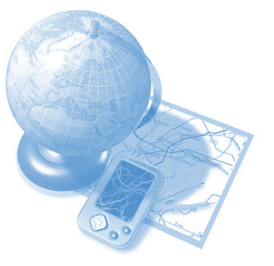

\author{
Steve Walker \\ Physical Sciences Centre \\ Higher Education \\ Academy Subject Network \\ Department of Chemistry \\ Donnan Laboratories \\ University of Liverpool \\ L69 7ZD \\ sk01@liv.ac.uk
}

\section{Outreach Activities: a summary for UK university science departments}

\begin{abstract}
The dictionary definition refers to surpassing, outwitting or the act of 'reaching out'. The Funding Councils see it as "widening access and improving participation in higher education...... to equip people to operate productively within the global knowledge economy. It also offers social benefits, including better health, lower crime and a more tolerant and inclusive society".
\end{abstract}

Here in the Physical Sciences, whilst reaching out to widen access is an important part of our agenda, we see Outreach activities as primarily being targeted at improving the recruitment and retention of students. Many Physical Science departments are struggling to attract sufficient numbers of students and virtually all of us are also unhappy that the more able students are not choosing science for their higher and further education. This has led to the complete closure of a number of departments; a merger with cognate disciplines for some, or relegation to a 'service teaching' role for others. Since 1996, 28 universities have stopped offering chemistry degrees and almost a third of university physics departments have closed in the same period. Despite this dramatic fall in capacity, there is still a shortfall that is a major cause of concern for all but a handful of institutions.

There is a great deal of confusion within Universities as to how and why this situation has arisen and in this article I will attempt to collect and summarise items that have a direct bearing on these issues.

The first part will include the results of surveys into student preferences, public attitudes to science and scientists and lecturers' own opinions on the subject. The second part will summarise the recommendations from a number of sources who have given much thought to alleviating the situation and the final section will look at a selected number of institutions that are actively generating materials and methods that could be more widely adopted in order to improve the current climate.

\section{Introduction}

The dictionary definition of outreach refers to surpassing, outwitting or the act of 'reaching out'. The Funding Councils see it as "widening access and improving participation in higher education...... to equip people to operate productively within the global knowledge economy. It also offers social benefits, including better health, lower crime and a more tolerant and inclusive society".

Here in the Physical Sciences, whilst reaching out to widen access is an important part of our agenda, we see Outreach activities as primarily being targeted at improving the recruitment and retention of students and more recently, playing a key role in promoting 'strategic and vulnerable subjects' eg Physical Sciences, Engineering and Mathematics.

This paper summarises the published information both in print and on the web which deal with the questions: 'Why are students turning away from the Physical Sciences' and 'How can we reverse this trend'. We also look at a selected number of initiatives that are actively generating materials and methods that might change the current situation.

\section{Background}

Chemistry departments are under pressure due to the recent drop in entrants. The numbers of pupils attempting Chemistry A-level has been declining since 1995, following a gradual and spasmodic increase in numbers from the 1960s. The recent absolute decline also reflects a greater relative decline in terms of a percentage of all A-level entries and as a proportion of the relevant 16 to 19 year old cohort. Compared with 1991, the overall numbers of A-level entries in 2005 were $12.1 \%$ higher. But entries in 
physics were $35.2 \%$ lower, entries in mathematics were $21.5 \%$ lower, and entries in chemistry were $12.6 \%$ lower. Since 1996, 28 universities have stopped offering chemistry degrees. Philip Kocienski, head of department at Leeds, says: "If the current trends continue, I estimate that there will be a maximum of 20 universities in the UK teaching and doing research in chemistry."

Physics is similarly under threat. A survey of 432 schools and colleges in England and Wales revealed that although A-level entries in all subjects have risen by $14.6 \%$ since 1990 , the number of physics entries had fallen by $38 \%$. Nearly $10 \%$ of state schools with sixth forms now do not offer Alevel physics, and of those that do $39.5 \%$ had five students or fewer taking it this year. Almost a third of university departments offering physics have closed in the past decade.

In a recent Institute of Physics report Lord May said "The profound problems facing science at A-level extend well beyond physics. We have consistently highlighted the general downward trend of students studying the sciences and if we fail to address this then we risk losing the ability to train the next generation of scientists, technologists and engineers".

There is a great deal of confusion within Universities as to how and why this situation has arisen. Those of us who work in the Physical Sciences often assume that the unpopularity of our subjects is related to public attitudes of fear, distrust and poor subject image. Furthermore, we have the feeling that our disciplines are 'hard' whilst all others are 'soft' and this deters potential applicants. Add to this the commonly-held view that science teachers are poorly qualified and motivated and that careers teachers do not understand the sciences and you have the recipe for a substantial self-inflicted inferiority complex. The fact that the majority of 'famous' personalities presenters, entertainers and celebrities, plus the opinion formers - politicians, journalists and writers, have no scientific grounding and are often openly antipathetic or derisive of scientific matters, simply compounds the issue.

\section{Surveys of Opinion}

It is often thought that we do not know what influences students in their choice of post-school studies and future employment. Whilst it may be that large-scale in-depth studies are thin on the ground, there is plenty of evidence pointing to the basic problems.

\section{Physics Students}

A survey of the attitudes of Physics students can be found in 'Getting Started in Pedagogical Research in the Physical Sciences', by Norman Reid (see Table 1).

One question explored what were the likely factors which attracted the students into physics as a degree course. This question was given to 218 level 1 and level 2 students taking courses in physics and asked them to look back: Which factor(s) influenced your choice of planned honours subject(s)?
There is no need to do more statistics on this. The pattern immediately tells us that, if we wish to attract more students into physics, then we can safely ignore most of the factors. It tells us that the school experience is by far the dominant factor. The quality of the school syllabus and the quality of the teachers are the critical factors. It is unlikely that we can influence the school physics curriculum although we might be able encourage able students to consider school teaching.

\section{Table 1: Factors influencing choice of planned honours subject(s)}

\section{$3 \%$ Friends \\ $49 \%$ Likely career opportunities}

$9 \%$ Demonstrations, exhibitions, festivals

$7 \%$ Any other factors (please list below)

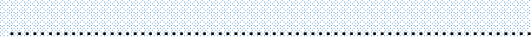

However, any efforts in arranging special events, demonstrations, science centres, and exhibitions are likely to have only marginal effects in attracting students towards physics and are unlikely to justify the effort, energy and expenditure. There is one area which is open to us - the perception of career opportunities. Other research in the same survey confirmed that this is an area where more information is needed by school pupils and students.

\section{GCSE Pupils}

A recent online survey by the OCR (Oxford, Cambridge and RSA \{Royal Society of Arts\}) examination board involved 950 pupils from Years 9, 10 and 11, across a range of schools (both public and independent) and range of abilities, between November 2004 and February 2005. This revealed some interesting attitudes.

- Over $50 \%$ said that science lessons were boring, confusing or difficult.

- $\quad 25 \%$ of GCSE Science students say they won't be doing science after Year 11.

- The Human Body and Earth \& Space are the most popular science subjects.

- 'Experiments in class' are the best thing about learning science followed by field trips and videos. 'Reading text books' or 'researching on the internet', are seen as some of the least effective methods, nominated by just $20 \%$.

- $77 \%$ of pupils believe that the science they learn in school will be useful to them in the future. However, Year 11 pupils are twice as likely $(30 \%)$ as Year 9 pupils $(16 \%)$ to say it will be 'not very useful/of no use' implying that the level of relevance diminishes as the subject's complexity grows.

- $92 \%$ say curing diseases is the most important priority for science.

- Astronaut tops the list of 'most interesting scientific professions'. 
- When asked to name a famous scientist, most students named Albert Einstein or Isaac Newton. With role models from centuries ago it's perhaps not surprising that when asked to describe a scientist the words 'boring', 'eccentric' and even 'dim' emerged. Just 7\% described scientists as 'cool' and only $6 \%$ 'fun'. On the plus side, $79 \%$ of pupils associated scientists with being clever (although perhaps to be clever is not cool).

- When asked what science subject they would take if it were not compulsory, $45 \%$ said they would take biology, $32 \%$ chemistry, $29 \%$ physics and $19 \%$ combined science but $16 \%$ would not choose any of them.

\section{Popular Opinion}

Physical Scientists often assume that the unpopularity of our subjects is related to public attitudes of fear, distrust and poor subject image. Admittedly there are problems associated with risk assessment and images of pollution but the products of science are widely respected and valued. Science is seen as important both by the public and the Government. However, many aspects are not presented or perceived as part of science. Examples of this are nanotechnology, which is perceived as engineering, and pharmaceuticals are not seen as products of chemistry and chemists. This means that the sciences do not benefit as much as they could from the respect given to their products.

A survey of adult public opinion in 2000 yielded the following major conclusions, which are often at variance with those held by school pupils.

- Three-quarters are 'amazed' by science.

- Two-thirds think it makes our lives better.

- Only $20 \%$ have no interest.

- $80 \%$ believe we should invest heavily.

- $70 \%$ approve of 'blue-sky' research.

- $43 \%$ think the benefits outweigh the disadvantages, $17 \%$ disagree.

- $43 \%$ think politicians support science 'for the good of the country', $25 \%$ disagree.

- $40 \%$ think the rate of progress is beyond government control but $30 \%$ disagree.

- $53 \%$ believe that politicians' decisions are swayed by the media with insufficient lead.

- $84 \%$ of people think scientists are valuable contributors and three-quarters think science is a good career choice.

- Two-thirds believe that scientists wish to improve our lives but the same proportion think we should listen more to ordinary people.

A similar survey was carried out in 2005 and revealed an increase in regard for science and scientists.

\section{Recommendations}

Two thorough and substantial documents have been written with particular relevance to science recruitment.

\section{Nick Jagger}

Nick is a Research Fellow of the Institute for Employment Studies, with over 20 years of policy research experience. He particularly concentrates on scientific, engineering, ICT 


\begin{tabular}{|c|}
\hline \multicolumn{1}{|c|}{ Medicines } \\
How medicines work \\
Enzymes \\
Receptors \\
History \\
Statistics \\
Drug synthesis \\
Design strategies \\
Examples \\
Antibacterials \\
Analgesics \\
Amphetamines \\
Tranquilisers \\
Antihistamines \\
Hormones \\
Hallucinogens \\
Homeopathics \\
Viagra, the Pill \\
Abuse
\end{tabular}

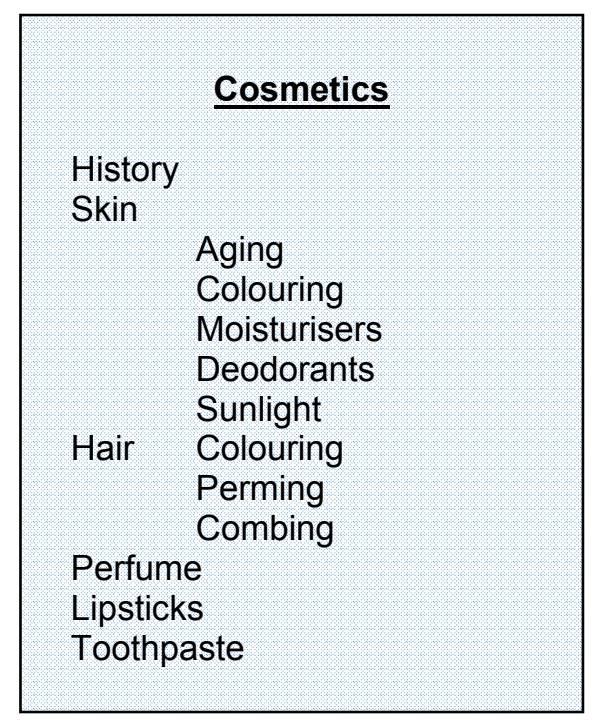

\section{Semiconductors}

Bonding in metals, insulators, and semiconductors

Impurities and Dopants

n-type and p-type

Zone refining

Chip fabrication

Nanotechnology

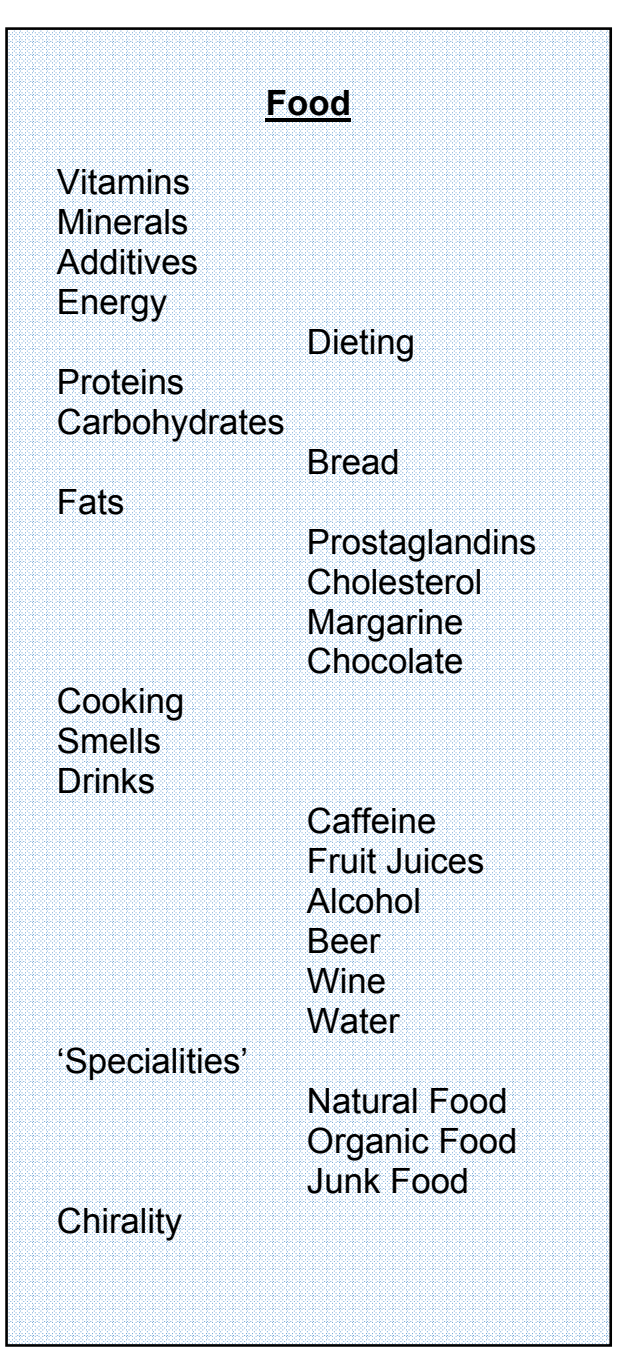

Table 3: Contents of other Case Studies from the Chemistry Box

problems. Unfortunately these teachers often do not have up-todate careers knowledge or use available materials. This suggests that there is a need for teachers to be encouraged to use appropriate material promoting science careers.

Understand the career and study aspirations of 16 to 19 year old students

It is surprising that it appears that the only study of the career and study aspirations of A-level students covered only Northern Ireland. If effective careers material and advice is going to be developed we need to know what resonates with 16 to 19 year olds.

\section{Engage in the development of} new curricula

It is known that science taught using up-to-date and everyday examples engage students better, and thus encourages take-up.

\section{Encourage a dialogue between industry and teachers}

It is known that industrial visits and industrial placements, if organised successfully, are very effective. However, work experience is often difficult to organise because of perceived health and safety problems.

\section{Understand why science} undergraduates choose science There is a need to understand why science undergraduates choose to study science and why those who are otherwise qualified choose not to study it.

\section{Urge universities to co-} operatively respond to university funding changes

The climate of rapid and relatively dramatic decline in the number of entrants has resulted in some universities increasing their entry through bursaries and other measures. This can only lead to a

\section{Pre-empt public misunderstanding of science and} technology

Actively engage in a debate about safety and ethics associated with technology, perhaps by trying to refocus the debate around physics and chemistry rather than the technology.

\section{Encourage science teachers to take-up and use} appropriate careers materials

The changes in the Careers Service and the increasing need for science teachers to provide careers advice causes more rapid decline of entrants at the other universities. This in turn could lead to the closure of more science departments to the long-term detriment of the disciplines.

University lecturers should be aware of and engage in the debate surrounding 14-19 education changes Curriculum changes undoubtedly have implications for the knowledge, skills and attitudes of entrants to chemistry courses in the future. Therefore, it is critical that those involved with university science engage with those developing any new curricula in a two-way dialogue. 


\section{Averil Macdonald}

Averil is a well known education consultant, science communicator and author. She makes a number of valuable points on recruitment to individual departments and improving the perception of science among the general population. She has quite specific recommendations for encouraging more students to study science post-16 and points out that whereas some 300,000 students are eligible to go on to A-levels or Highers in the physical sciences each year, only around 40,000 - 50,000 choose to do so (the proportion in Scotland is $55 \%$; in England and Wales it is only $10 \%$ !). There is no doubt that the majority has already decided upon their post-16 subject direction by the age of 15 and projects targeting this age group may influence some to consider sciencebased careers who would otherwise be persuaded to choose non-science subjects post-16. Averil's comments are aimed squarely at the practitioner the following is based upon her suggestions.

\section{Produce resources}

Teaching Resources which directly target elements of the $14-16$ age range will be of great use to teachers if they introduce some cutting edge science that does not feature in text books and to which teachers may not have easy access.

\section{Activities and Visits to Universities}

Masterclasses, Lectures, Visits and Open Days are a good way to introduce 15 year old students to what university life is like. However if this is done on a departmental basis the number of students invited from any one school will need to be restricted and this will result in teachers sending the best students only and we end up preaching to the converted again.
Worksheets must be able to be photocopied, or easily downloaded from a website or a CDROM. They should fit onto an A4 sheet and must provide information as well as activities such as questions, quizzes, word searches, crosswords, comprehension exercises, data analysis (a great favourite with teachers!) etc. It is essential that the demand level is appropriate to the curriculum requirements and that the language level is not too high. Provision of answers for the teachers is always very much appreciated.

Websites should also provide information and associated activities such as those above. Students love interacting with websites but will not read vast amounts of text. Animations that illustrate a phenomenon are particularly good. Supplying the material on a CDROM allows the school to network the materials.

Videos or DVDs make a popular addition to a teacher's resources but must last for less than 30 minutes (preferably in short, say 5 minute, segments) as students' attention wanders. The topic must be directly related to the curriculum and ideally a topic for which other materials are not available eg manufacturing processes, nuclear power, sustainable energy, astronomy, medical physics or forensic science.

Careers Materials focusing on opportunities for those with science qualifications are often lacking in schools. Many 14 16 year olds are often advised about career possibilities by people who have no background in the sciences and therefore have little idea about the range of opportunities that science opens up to them.
General Open Days which can accommodate all a school's 15 year old students (perhaps 250) are much more effective but really have to be organised across the whole faculty, if not the whole university.

\section{Activities and Lectures in School}

Lectures should address the target audience and be of an appropriate level - some groups will be mixed ability and not all high flyers. They must also fit into the school timetable, lasting 45 minutes at most. The best lectures use a range of elements including images and practical demonstrations. Don't use a series of PowerPoint slides listing bullet point after bullet point as 15 year old students lose concentration far more quickly than conference delegates.

Activity days (or experience days), where students try out a range of 'experiments', have the benefit that they can accommodate all the members of a year group rather than just a few. There are two problems here - providing the materials and the time available. Schools will be reluctant to change the whole school timetable however good the event and other subject teachers will rarely release students to undertake a science activity when they are timetabled to do other studies. Ideally the activities should be able to accommodate a whole class (around 30) or multiples of 30 up to a half-year group (perhaps 150), which may be timetabled at the same time. Each repeat should fit into a school lesson - which varies from school to school but is most likely to be between 50 and 70 minutes. 
Competitions are popular with universities but not as popular with teachers as they can rarely put in the additional time and money required to run the competition in school time and after-school activities are constrained by the need to get students onto school buses. Competitions will typically attract most entrants from the independent sector as they are less constrained by time and money. Some competitions have proved to be exceedingly popular (see below).
- A collection of 60 Chemistry experiments ranging in difficulty from those requiring little supervision to 'demonstration-only' versions.

- Games.

- Videos from the Liverpool University video library. These can be used as complete films or selected snippets may be pulled.

- Salt, 30 mins.

- Liquid Air, 55 mins.

- Oxidation, 30 mins.

\begin{tabular}{|l|l|l|l|}
\hline 'Roulette Scam' & $\begin{array}{l}\text { Mechanics and } \\
\text { elastic/inelastic } \\
\text { collisions }\end{array}$ & $\begin{array}{l}\text { VIDEO CLIP: } \\
\text { Dropping a } \\
\text { hammer and } \\
\text { feather on the } \\
\text { Moon. }\end{array}$ & $\begin{array}{l}\text { Coefficient of } \\
\text { restitution for a } \\
\text { cow pat! }\end{array}$ \\
\hline $\begin{array}{l}\text { Kinetic and } \\
\text { potential energy } \\
\text { gives } \text { e as function } \\
\text { of initial and } \\
\text { rebound heights }\end{array}$ & $\begin{array}{l}\text { ACTIVITY: } \\
\text { Measure } \\
\text { bounces (and } e) \\
\text { of different types } \\
\text { of ball }\end{array}$ & $\begin{array}{l}\text { Show how LTA } \\
\text { uses these simple } \\
\text { techniques to } \\
\text { assess tennis } \\
\text { balls and ball-turf } \\
\text { interactions. }\end{array}$ & $\begin{array}{l}\text { THOUGHT } \\
\text { EXPERIMENT: } \\
\text { Perpetual Motion } \\
\text { Machines - what if } \\
\text { e > 1? Cartoon of } \\
\text { perpetual motion } \\
\text { machine. }\end{array}$ \\
\hline $\begin{array}{l}\text { DRAMATIC } \\
\text { DEMONSTRATION: } \\
\text { The pesky ping- } \\
\text { pong ball! }\end{array}$ & $\begin{array}{l}\text { Slides to explain } \\
\text { mathematically } \\
\text { the rebound } \\
\text { phenomenon }\end{array}$ & $\begin{array}{l}\text { Centre of Mass } \\
\text { and motion in a } \\
\text { gravitational field }\end{array}$ & $\begin{array}{l}\text { Compute the time } \\
\text { taken for a ball to } \\
\text { drop to the floor } \\
\text { from height, } h\end{array}$ \\
\hline $\begin{array}{l}\text { ACTIVITY: Measure } \\
\text { your reaction time }\end{array}$ & $\begin{array}{l}\text { QUIZ: Hanging in } \\
\text { the air- } \\
\text { footballers }\end{array}$ & $\begin{array}{l}\text { IMPROBABLE } \\
\text { RESEARCH: Flea } \\
\text { Jumping }\end{array}$ & $\begin{array}{l}\text { CHALLENGE: } \\
\text { The Subtle Bomb } \\
\text { Drop }\end{array}$ \\
\hline $\begin{array}{l}\text { QUIZ: The tumbling } \\
\text { telescope }\end{array}$ & $\begin{array}{l}\text { QUIZ: Fight } \\
\text { flabbiness with } \\
\text { physics }\end{array}$ & $\begin{array}{l}\text { QUIZ: Flower } \\
\text { power - fastest } \\
\text { plant seed } \\
\text { ejection }\end{array}$ & $\begin{array}{l}\text { FINAL VIDEO } \\
\text { CLIP: Stick motion } \\
\text { beats gravity }\end{array}$ \\
\hline
\end{tabular}

Table 5: The Balls in Flight Case Study from the Physics Box
- E-learning modules covering particular areas of the school syllabus usually thought of as 'difficult' eg The Mole, Spectroscopy (IR, NMR, MS), Kinetics, Particles and Waves in Physics.

- $\quad$ The Chemistry Tutor II (Web-based)

\section{- $\quad$ Case Studies (PowerPoint)}

\section{Waking without Chemistry}

The backbone of the series is a light-hearted look at what a school pupil might encounter upon awakening and preparing for school should there be no such thing as a chemical industry. It contains lots of sound effects, videos and fancy transitions plus a little humour. It deals with topics such as semiconductors, electricity and lighting, polymers, electrochemistry, medicine, cosmetics, food, transport and clothing. The final part suggests a few topics that might assume importance in the future. Using this as a starting

\section{Resources}

Outreach activities and the materials produced to support them bring benefits beyond the original institutions; fostering a general improvement in attitude to both the subject and $\mathrm{HE}$. In several areas, the funding for activities is conditional on free dissemination to all appropriate institutions. We are in the process of collecting information on the availability of these items and this will be published on our website in the near future.

Two substantial collections of resources have been produced by the Centre.

\section{The Chemistry Box}

The Chemistry Box is written and published by the Centre and the resources may be downloaded from our website.

- Spreadsheets downloaded from government statistics covering the remuneration and employment of scientists. Presented via PowerPoint.

- Useful data for visiting speakers extracted from recent studies covering public attitudes to science and University admissions procedures.

- Practical resources such as structure-drawing software. point, there are additional cases with the following contents:

- Semiconductors

- Cosmetics

- Food

- Medicine

\section{The Physics Box}

The Physics Box is written and published by the Centre and the resources may be downloaded from our website.

- Exemplar Case Studies (Powerpoint presentations) around 20 are available:

\section{Amaze Your Mates}

This case study is simply a collection of off-beat puzzles and activities (see Table 4)

\section{Balls in Flight (see Table 5)}

\section{Other PowerPoint presentations (see Table 6)}

- Exemplar quiz/challenges on individual Powerpoint presentation slides to stimulate discussion - these are logical, mathematical and physics puzzles and activities. 


\begin{tabular}{|l|l|l|l|}
\hline $\begin{array}{l}\text { Become an } \\
\text { amateur scientist }\end{array}$ & $\begin{array}{l}\text { Communication } \\
\text { and Coding }\end{array}$ & Defying Gravity & $\begin{array}{l}\text { Electrons in } \\
\text { Motion }\end{array}$ \\
\hline Kitchen Physics & $\begin{array}{l}\text { Magnetism and } \\
\text { Magnetic Devices }\end{array}$ & Natural Disasters & Natural Sounds \\
\hline $\begin{array}{l}\text { Our Natural } \\
\text { Environment }\end{array}$ & $\begin{array}{l}\text { Physics - a } \\
\text { sideways view }\end{array}$ & $\begin{array}{l}\text { Physics Tricks and } \\
\text { Optical Illusions }\end{array}$ & $\begin{array}{l}\text { Quest for } \\
\text { Invisibility }\end{array}$ \\
\hline $\begin{array}{l}\text { Relativity \& } \\
\text { Reference } \\
\text { Frames }\end{array}$ & $\begin{array}{l}\text { Renewable Energy } \\
\text { Resources }\end{array}$ & The Doppler Effect & $\begin{array}{l}\text { The Radio } \\
\text { Universe }\end{array}$ \\
\hline Quiz Questions I & Quiz Questions II & Quiz Questions III \\
\hline \multicolumn{3}{|l}{ Table 6: Other Case Studies from the Physics Box } \\
\hline
\end{tabular}

- Lots of individual files containing suitable newspaper articles, short scientific texts, images, sound snippets, video clips, cartoons and background text relevant to GCSE level curricula.

- Lists of websites are given which are excellent resources for on-line teaching, books and also articles for further reading and descriptions of materials for demos/activities.

- Links to different careers: application of physical principles in everyday activities.

\section{Activities}

Most departments carry out some or all of the activities listed above: master classes, experiments at school, lecture programmes and so on. The following is a selection of national events that departments may subscribe to, or become associated with.

\section{Chemistry Week}

The RSC Chemistry Week is a themed week of events that is held every two years to promote a positive image of chemistry and increase the public understanding of the importance of chemical science in our everyday lives. As well as national events, activities are organised throughout the UK and the Republic of Ireland by RSC Local Sections.

The next Chemistry Week is due in 2007.

\section{Lab in a Lorry}

Lab in a Lorry is an interactive mobile physics laboratory staffed by volunteer practising scientists and engineers. The aim is to give young people aged 11-14 the opportunity to do experimental science in the way it actually happens; exploratory, accidental, informed by curiosity and intuition, but also bounded and guided by the experience and insight of practicing scientists. It is a joint initiative between the Institute of Physics and the Schlumberger Foundation and one of several Institute of Physics outreach programmes.

\section{National Science Week}

National Science Week aims to celebrate science and its importance to our lives, providing an opportunity for people of all ages across the UK to take part in science, engineering and technology activities. Hundreds of thousands of people across the UK take part in National Science Week activities every year.

The British Association coordinates National Science Week, providing a national context for each event.
Young Analyst Competition Organised by the Analytical Division (AD) of the RSC, this encourages younger Analytical Chemists and involves them at all levels of $A D$ activity. Last year this involved over 200 schools in regional heats and a national final.

\section{Salters' Festival}

The Salters' Festivals of Chemistry are an initiative of the Salters' Institute. Their objective is to help promote the appreciation of chemistry and related sciences among the young.

Salters' Festivals run from late March to mid June and provide the opportunity for enthusiastic young students to spend a day in a university department and to take part in practical chemistry activities.

\section{CREST Awards}

Celebrating CREativity in Science and Technology BA CREST is a nationally recognised accreditation scheme for project work in the fields of science and technology. Aimed at students aged 11-19, the awards encourage students to develop their scientific curiosity, problem-solving and communication skills.

\section{BRONZE}

10 hours of project work Typically for ages 11-14

\section{SILVER}

40 hours of project work Typically for students aged $14-16$ Links with industry encouraged

\section{GOLD}

100 hours of project work

Typically for students aged $16+$

Students linked with mentor from industry or higher education

Can accredit Nuffield Bursary placements and Engineering Education Scheme (EES) project work

Table 7: The Crest Award Levels

Through a mentoring system, the scheme facilitates links between schools and industry or higher education.

The awards are available in Science or Technology at three levels:

Students who have completed BA CREST project work have the opportunity to display their work at Regional Finals. Outstanding projects are selected for the prestigious national BA CREST Science Fair (http://www.the-ba.net/the-ba/ ResourcesforLearning/BACRESTScienceFair/) 


\section{The Science Ambassadors Programme}

The Department of Trade and Industry (DTI) funded Science and Engineering Ambassadors programme (http:// www.setnet.org.uk/cgi-bin/wms.pl/181\#TI) aims to promote STEM (science, technology, engineering \& maths) by providing enthusiastic, vetted volunteers to work with young people and teachers in schools.

Science and Engineering Ambassadors can get involved in a whole range of activities and events, either organised and managed by the local SETPOINT or working with other organisations and schemes aimed at enthusing school-age children in STEM.

Examples of activities which are happening include:

- Ambassadors from large multinational companies linking with schools close to their sites and taking after-school engineering clubs

- Industrial volunteers working with classes on projects for GCSE Applied Science and Engineering

- Young IT professionals e-mentoring students in local schools

\section{Aimhigher}

Aimhigher is a national programme which aims to widen participation in higher education by raising the aspirations and developing the abilities of people from under-represented groups. Aimhigher partnerships build cross-sector relationships which break down the barriers which institutions and systems can unwittingly create for learners.

Funded activities include summer schools (http:// www.hefce.ac.uk/widen/summsch/) to give school pupils a taste of university life, mentoring by students, and visits by staff from higher education providers to work-based training providers.

Funded projects relevant to the physical sciences are described in detail on the web pages of the RSC, IOP and SETNET and many of these have (or will have) resources available for download.

\section{Young Engineers}

Young Engineers' aim is to inspire young people to develop an interest in engineering, and, in doing so, recognise the importance and excitement of engineering as a future career. It develops and manages a national network of extracurricular engineering clubs in both the primary and secondary sectors and runs a number of engineering challenges and competitions. There is a great deal of overlap with the physical sciences.

\section{Particle Physics and Astronomy Research Council (PPARC) Master Classes}

These take place in almost every University and form part of PPARC's overall communications strategy, involving public engagement and public accountability.

The aim is to promote the understanding, appreciation and awareness of science areas so that young people's fascination for astronomy, space and particle physics is translated into an understanding and interest in all scientific areas, and a readiness to consider a scientific career.
CETLS

The HEFCE Centres for Excellence in Teaching and Learning (CETL) initiative has two main aims: to reward excellent teaching practice, and to further invest in that practice so that CETLs funding delivers substantial benefits to students, teachers and institutions. There are four centres that are of interest to us and they are intending to provide a great deal in the way of resources, courses, good practice and so on which will be made freely available to all. Their contact details are to be found in the references section

\section{Selected References}

- Philip Kocienski is quoted by Daniel Clery in 'Darwinian' Funding and the Demise of Physics and Chemistry, Science, Vol 307, Issue 5710, 668-669, 4 February 2005 [DOI: 10.1126/science.307.5710.668]. (http:// www.sciencemag.org/cgi/content/full/307/5710/668)

- Outreach - a guide to working with schools and colleges, Averil Macdonald http://www.physsci.heacademy.ac.uk/publications/ practiceguide/outreachpracticeguide.pdf. A profile of Averil can be found at http://www.bbc.co.uk/ schools/communities/onionstreet/liveguests/profiles/ averilmacdonald.shtm

- Getting Started in Pedagogical Research in the Physical Sciences, Norman Reid

http://www.physsci.heacademy.ac.uk/publications/ practiceguide/gettingstarted.pdf

- $\quad$ Students \& Science Report, OCR http://www.gcse-science.com/file_downloads/ pgd_files_218_2.pdf

- Science and the Public: A Review of Science Communication and Public Attitudes to Science in Britain OST and the Wellcome Trust, 2000

- $\quad$ Science in Society, OST and DTI, 2005

- BBC report summarising the state of Physics education http://news.bbc.co.uk/1/hi/education/4450208.stm

- The Right Chemistry: The choice of chemistry courses and careers, Nick Jagger, Institute for Employment Studies, 2004

- $\quad$ Centre for Effective Learning in Science (CELS). Nottingham Trent University http://www.ntu.ac.uk/cels/

- Centre for Open Learning in Mathematics, Science, Computing and Technology. Open University http://cetl.open.ac.uk/colmsct/

- Centre for Excellence in Innovative Physics Teaching. Open University http://cetl.open.ac.uk/picetl/

- Bristol ChemLabS CETL (Bristol Chemical Laboratory Sciences). University of Bristol http://www.chm.bris.ac.uk 